(C) The Author(s), 2021. Published by Cambridge University Press for the British Institute of International and Comparative Law. This is an Open Access article, distributed under the terms of the Creative Commons Attribution licence (https://creativecommons.org/licenses/by/4.0/), which permits unrestricted re-use, distribution, and reproduction in any medium, provided the original work is properly cited.

\title{
TRANSCENDING THE INDIVIDUAL/COLLECTIVE MINORITY RIGHTS DIVIDE: A PROCEDURAL SOLUTION
}

\author{
ZSOLT KÖRTVÉLYESI*
}

\begin{abstract}
Relying on examples from international, EU and comparative law and drawing on insights from the class action literature, this article argues that important advances in minority rights protection can be achieved without the revision of substantive legal provisions and the full-scale embracing of collective rights. Allowing minority members to present their claims on behalf of a larger group (collective procedure), even when such claims ultimately rest on the rights of individuals as opposed to those of the group, strengthens minority rights and can transform our vision of them. An overview of eight interrelated benefits shows not only how these advantages occur, but also why the procedural approach avoids the issues that motivate negative critiques of group rights.
\end{abstract}

Keywords: human rights, group rights, collective procedure, class action, minority rights.

\section{INTRODUCTION}

There has long been a tension between individual-only approaches to minority rights and those allowing for collective or group rights, ${ }^{1}$ as is apparent from debates concerning minority rights and multiculturalism. ${ }^{2}$ Both sides raise

* Researcher, Institute for Legal Studies, Centre for Social Sciences, Hungarian Academy of Sciences and ELTE University, kortvelyesi.zsolt@tk.mta.hu. I would like to thank the numerous mentors, colleagues and friends who have commented on this idea, but who are in no way responsible for what it became, including Judit Tóth, Tibor Várady, and Hurst Hannum. Projects 124806 and 124804 have been implemented with the support of the National Research, Development and Innovation Fund of Hungary, financed under the FK and PD funding schemes, respectively.

1 This article will not differentiate between collective and group (group-sensitive, groupspecific, etc) rights. See, for example, TW Pogge, 'Group Rights and Ethnicity Part III: The Normative Status of Ethnicity: Section 7' (1997) 39 NOMOS 187. While the author is aware that collective rights (rights held jointly by members) and group rights (that might include rights that no single individual can claim) can refer to different sets of rights, the argument is that procedural aggregation circumvents the surrounding debates. The notions of collective and group rights are important since purely individual approaches can fail to address the needs of members of a minority in all instances. See S Miller, 'Collective Rights' (1999) 13 Public Affairs Quarterly 331.

2 See, for example, W Kymlicka et al., The Rights of Minority Cultures (Oxford University Press 1995); D Sanders, 'Collective Rights' (1991) 13 HumRtsQ 368; PV Ramaga, 'The Group Concept in Minority Protection' (1993) 15 HumRtsQ 575; A Buchanan, 'The Role of Collective Rights in the Theory of Indigenous Peoples' Rights' (1993) 3 TransnatlL\&ContempProbs. 89; P Jones, 'Human Rights, Group Rights, and Peoples' Rights' (1999) 21 HumRtsQ 80; J Donnelly, Universal Human Rights in Theory and Practice (Cornell University Press, NY 2013); N Lerner, Group Rights and Discrimination in International Law, vol 77 (Martinus Nijhoff Publishers 2003). 
legitimate concerns: there are valid claims that go beyond strictly individual rights; however, the concept of group rights also holds dangers, for example, of internal oppression. ${ }^{3}$ This article explores the possibility of going beyond this dichotomy and ameliorating these concerns by enforcing rights through collective procedures. It argues that adopting collective procedures for the enforcement of minority rights helps minority rights by extending the ability of law to address inequalities, while also taking account of concerns that collective and group rights threaten individual rights.

Individual rights go a long way in protecting members of minority groups. Nevertheless, otherwise legitimate individualist constraints can filter out many claims that are dispersed, arise from systemic trends or are difficult or impossible to fit within an individual-based legal framework. As Samuel Bagenstos critically notes: 'By focusing on discrete, identifiable acts of wrongdoing undertaken by specific, blameworthy individuals, the law failed to provide a meaningful response to structural or institutional discrimination that cannot be attributed to the fault of a particular racist or sexist.' ${ }^{4}$

Constraints may be especially restrictive of minority claims. Consider genocidal acts in which no rightful heir survives the purge, potentially meaning that perpetrators are not called on to provide compensation. At the other end of the scale, there may be a pattern of dispersed violations that are systemic but individually too small to be worth pursuing, thus these may also not be addressed through strictly individualist legal approaches. Denial of the right to use a minority language, for example, rarely leads to large numbers of individual victims claiming compensation. The same holds true for desegregation claims: those responsible for maintaining segregation are rarely made to fully compensate individuals for the detrimental impact it has had on their life chances. The list goes on, and the nationalist zeitgeist and securitising trends make it unlikely that important advances can be expected in the robust protection of minority rights in the foreseeable future. Joshua Castellino argues that given the political mood, there is a need for pragmatic and targeted approaches, ${ }^{5}$ while Kymlicka calls for new strategies 'to revive the flagging political project of diversity in Europe and elsewhere', given the 'growing public disenchantment'. ${ }^{6}$

For an earlier exploration, see Y Dinstein, 'Collective Human Rights of Peoples and Minorities' (1976) 25 ICLQ 102.

3 See Chapter 8: 'Toleration and Is Limits' in W Kymlicka, Multicultural Citizenship (Clarendon 1995) 153-72.

4 S Bagenstos, 'Litigation for the People' (2020) 67 Dissent 174, 175.

5 J Castellino, 'Identity and Human Rights in a "Populist" Era: Urging Caution and Pragmatism in Minority Rights Protection' in A-M Bíró (ed), Populism, Memory and Minority Rights (Brill Nijhoff 2018).

${ }^{6}$ W Kymlicka, 'Defending Diversity in an Era of Populism: Multiculturalism and Interculturalism Compared' in N Meer, T Modood and R Zapata-Barrero (eds), Multiculturalism and Interculturalism: Debating the Dividing Lines (Edinburgh University Press 2016) 174. 
There is, however, another tendency that shows promise. In an era in which even a single act or omission can have far-reaching consequences and result in a multiplicity of claims that may overburden institutions, the need for systemic responses has been recognised. ${ }^{7}$ There has been a proliferation of proposals and regulations permitting judicial and quasi-judicial bodies to consider sets of similar cases, ranging from national laws that permit group actions involving members who have not expressly opted in, to international attempts to address mass and repeat violations. This trend is partly driven by the widespread nature of violations, such as in the impact of corporate activity. ${ }^{8}$ Measures often target groups seen as vulnerable or less powerful, for example, in the context of consumer protection, ${ }^{9}$ but there have also been procedural solutions in the human rights field, such as the pilot judgment procedure before the European Court of Human Rights (ECtHR) ${ }^{10}$ and the system of collective complaints under the European Social Charter. ${ }^{11}$

Comparative scholarship has also shown the benefits of collective procedures, highlighting their regulatory potential ${ }^{12}$ and arguing for the use of class actions by international human rights bodies, ${ }^{13}$ including improving the pilot judgment procedure before the ECtHR, ${ }^{14}$ and in civil law jurisdictions generally. ${ }^{15}$ The goal of this article is more specific: it aims to show how collective procedures can help minority claims.

${ }^{7}$ For an overview of international responses to mass violations, see L Oette, 'Bringing Justice to Victims? Responses of Regional and International Human Rights Courts and Treaty Bodies to Mass Violations' in C Ferstman, M Goetz and A Stephens (eds), Reparations for Victims of Genocide, War Crimes and Crimes against Humanity (Brill Nijhoff 2009).

${ }^{8}$ See, for example, the Okpabi litigation, to be discussed later. Another example is the $V W N O x$ Emissions Group Litigation (with about 91,000 potential claimants) that was not only recognised by a Group Litigation Order by the High Court in London, but which also led to similar group claims being filed (and settled) in Australia (with around 100,000 claimants) and in Germany (with around 400,000 claimants). M Weller, 'The VW NOx Emissions Group Litigation, [2019] EWHC 783 (QB), and (Some Aspects of) CoL' (ConflictofLaws.net, 7 April 2020) < https://conflictoflaws.net/ 2020/the-vw-nox-emissions-group-litigation-2019-ewhc-783qb-and-some-aspects-of-col/?print=pdf $>$.

9 Directive (EU) 2020/1828 of the European Parliament and of the Council of 25 November 2020 on representative actions for the protection of the collective interests of consumers and repealing Directive 2009/22/EC [2020] OJ L409/1 (Directive on Representative Actions for Consumers).

${ }^{10}$ European Court of Human Rights, 'Pilot-Judgment Procedure. Information Note Issued by the Registrar' <https://www.echr.coe.int/Documents/Pilot_judgment_procedure_ENG.pdf>.

11 'Collective Complaints' (European Social Charter) <https://www.coe.int/en/web/europeansocial-charter/collective-complaints-procedure> .

12 SI Strong, 'Regulatory Litigation in the European Union: Does the U.S. Class Action Have a New Analogue?' (2012) 88 NotreDameLRev 899.

13 WJ Aceves, 'Actio Popularis - The Class Action in International Law' (2003) 2003 University of Chicago Legal Forum 353.

${ }^{14}$ T Sainati, 'Human Rights Class Actions: Rethinking the Pilot-Judgment Procedure at the European Court of Human Rights' (2015) 56 HarvIntlLJ 147.

15 A Gidi, 'Class Actions in Brazil: A Model for Civil Law Countries' (2003) 51 AmJCompL 311. 
Allowing minority claims to rely on collective procedures provides legal avenues and added guarantees for many otherwise unenforced rights. The argument is not meant to suggest that a collective approach should supplant individual procedures, ${ }^{16}$ nor that it is always superior. Neither is it being argued that when a case is litigated as a collective procedure, all remedies should likewise be collective. There are contexts in which other forms of enforcement, such as public interest litigation (actio popularis) and centralised enforcement, could be more effective and, indeed, these avenues may offer comparable protection for victims who fear retaliation. ${ }^{17}$ Furthermore, collective litigation procedures can allow for some individualised remedies.

Thus, the central point is not to argue that collective procedures and remedies are always preferable, but simply to explain that, unless appropriate collective procedures are available, the legal system will leave certain minority claimants without adequate recourse for enforcing their rights.

The merits of the proposal are evident when viewed from the premise of recognising the importance of collectivities. However, in order to make the argument more inclusive, this article works from an individualist premise and argues that making collective procedures available to enforce minority rights is an appealing option, even when considered from a more traditional individual rights perspective.

Existing minority rights norms on the international level ${ }^{18}$ remain largely grounded in the individualist approach, ${ }^{19}$ with the notable exception of the rights of indigenous peoples, ${ }^{20}$ even if occasionally collective terminology (more on protection than on rights) ${ }^{21}$ leads some to believe that groups also

16 For an argument, based on an overview of EU law, that collective mechanisms should work in addition to individual procedures, see C Warin, 'Individual Rights and Collective Interests in EU Law: Three Approaches to a Still Volatile Relationship' (2019) 56 CMLRev 463.

17 'Class action designation also provides a degree of anonymity to victims who might otherwise face repercussions from the defendants for filing individual lawsuits.' Aceves (n 13) 354 .

18 The core documents include Article 27 of the International Covenant on Civil and Political Rights, and the UN Declaration on the Rights of Persons Belonging to National or Ethnic, Religious and Linguistic Minorities, UNGA Res 47/135 (18 December 1992) UN Doc A/RES/47/135; in Europe, the European Charter for Regional and Minority Languages, and the Framework Convention for the Protection of National Minorities.

19 P Thornberry, 'Self-Determination, Minorities, Human Rights: A Review of International Instruments' (1989) 38 ICLQ 867.

${ }^{20}$ UN Declaration on the Rights of Indigenous Peoples, UNGA Res 61/295 (13 September 2007) UN Doc A/RES/61/295; an earlier and binding document: ILO Convention (No 169) concerning indigenous and tribal peoples in independent countries (adopted 27 June 1989, entered into force 5 September 1991) 1650 UNTS 383.

21 ICCPR Article 27 combines a clear individualist language ('persons belonging to...') with a nod to the collective aspect ('in community with others'). See, for example, J Pejic, 'Minority Rights in International Law' (1997) 19 HumRtsQ 666, 674. Article 1 of the UN Declaration on Minorities refers to the protection of the existence and identity of 'minorities', just like the Framework Convention and the Genocide Convention (General Assembly Resolution 260 A (III) of 9 December 1948) talk about the protection of the existence of groups (one might be forgiven to see in these instruments, the survival of the interwar 'minority protection' regime). This does not translate to the claim that these norms recognise collective rights. 
hold certain rights. ${ }^{22}$ This article argues that collective procedures will help, whether or not we accept collective or group rights, and will also work in a setting where only individual rights and claims ${ }^{23}$ are recognised. Therefore, debates around the existence and desirability of collective or group rights under international (minority) law $^{24}$ are circumvented by proposing that collective procedures also work with strictly individualist readings, while bringing benefits that proponents of an approach going beyond individualism would welcome. ${ }^{25}$

The rights and related claims ${ }^{26}$ may involve remedies for various harms, for example, for the effects of colonisation (see the indigenous claims for loss of land and culture) or, more widely, comparable claims by minorities marginalised in the process of nation-building. We may also consider remedies for genocide and other mass killings targeting minorities (the Holocaust, genocide and 'ethnic cleansing' in the Balkans, etc). Cases may revolve around other discriminatory policies, such as in the cases of slavery, apartheid, and forced removal from families or territories (as in the Stolen Generation's forced separation and transfer to camps in Australia and Canada). ${ }^{27}$

This article acknowledges the diversity of claims, including the possibility of there being mutually exclusive claims, such as calls for integrated education in a non-segregated environment and aspirations for separate minority institutions. However, it is submitted that any claim brought on behalf of minorities can be more adequately dealt with when collective procedures are available, even when one takes into account concerns related to agency and representation (see Section II.F below).

22 Normative theories on the existence of collective rights based on individual interests: J Raz, The Morality of Freedom (Clarendon Press 1986) 207-9; M Freeman, 'Are There Collective Human Rights?' (1995) 43 PolStud 25.

${ }_{23}$ As collective procedures help minority claims regardless of whether they are presented as tort claims or directly as human rights claims, both types will be included in the discussion.

24 Donnelly (n 2) 45-51.

25 The author is certainly aware that no matter how open the argument seeks to remain, there will be sceptics, including in particular those who are not persuaded that courts can or should deal with collective claims. It can only be hoped that the examples of how courts have been dealing with collective claims, and how many of them are seeking more efficient mechanisms for dealing with mass claims, make this argument at least plausible. This article works from the premise, apparent from the examples given, that courts dealing with human rights are already dealing with claims for structural changes. The only point that can be added is to refer to theories that serve as the background for this proposal, adopting a 'public law reading' of litigation. A Chayes, 'The Role of the Judge in Public Law Litigation' (1976) 89 HarvLRev 1281; OM Fiss, 'The Political Theory of the Class Action' (1996) 53 WashLeeLRev 21; H Hershkoff, 'Public Law Litigation: Lessons and Questions’ (2009) 10 HumanRtsRev 157. See also Section II, F below.

26 The arguments are equally applicable to rights, as well as other types of claims, but this article is primarily concerned with the former. Most litigation that seeks to enforce claims that touch upon minority members' interests more generally will usually also advance minority rights.

27 One could also mention the Japanese-American internment, infamously discussed in Korematsu v United States 323 US 214 (1944). 
A collective procedure can also help in the fight against other discriminatory practices that impact disparately on certain minority groups. The discussion will include discrimination claims in minority claims, following the lead of minority rights documents that treat non-discrimination as a keystone of minority rights protection. $^{28}$

Naturally, areas will remain where legal input will do little to rectify the situation. The closer we move toward self-determination claims and questions of redistribution, the less likely it is that courts will be able to provide adequate guarantees. ${ }^{29}$

Section II focuses on what constitutes a collective procedure, as well as on current practice, particularly within international human rights law. It is then argued that the expansion of access to justice resulting from collective procedures is not merely a question of convenience; on the contrary, it is a matter of human rights $(\mathrm{A})$.

The subsequent sections discuss the various benefits that collective procedures may bring to minority rights litigation, addressing related concerns and possible criticisms: Collective procedures help to address violations with dispersed effects (B); claims that are only cognisable on the group level (C); and claims where evidence is largely limited to the collective level (D). Collective procedures allow for remedies that correspond more closely to patterns in the violations, with the possibility of combining individual and collective measures (E). They also make it easier for courts to address the problem of adequate representation, an issue that is often neglected in individual litigation, but impacts on the rights of larger groups (F). The aggregating effect of collective procedures may help to devise meaningful material sanctions, leading to large-scale redistribution from violators to victims, which contributes to deterrence against further violations

28 See, for example, Pejic, reviewing international minority rights documents which 'provide that, at a minimum, states are prohibited from discriminating against minorities.' Pejic (n 21) 675-81. See also the history of minority protection, showing that equal treatment requirements go back to, at least, the interwar period: J Ringelheim, 'Minority Rights in a Time of Multiculturalism - The Evolving Scope of the Framework Convention on the Protection of National Minorities' (2010) 10 HRLRev. 99, 104. It has even been argued that the leading and binding European treaty on national minorities, the Framework Convention for the Protection of National Minorities, is, to a large extent, but a variation of the themes of non-discrimination and existing human rights: 'While the Convention is designed to protect minority rights, several of the articles are simple nondiscrimination provisions', which, argues Gilbert, makes them 'redundant' in light of ECHR non-discrimination protection. G Gilbert, 'The Council of Europe and Minority Rights' (1996) 18 HumRtsQ 160, 180.

29 We refer here only to the debate on whether to allow collective procedures within the UN framework, eg before the Human Rights Committee, would (or should) open the way to selfdetermination claims, given that it is the individual procedural aspect that made the Committee conclude that it cannot consider claims under Article 1 of the International Covenant on Civil and Political Rights. See, for example, the Mikmaq tribal society v Canada, Comm No 78/1980 (30 September 1980), UN Doc Supp No 40 (A/39/40) at 200 (1984); and Ivan Kitok v Sweden, Comm No 197/1985, CCPR/C/33/D/197/1985 (1988). 
(G). Finally, collective procedures can increase the efficiency and coherence of judicial procedures $(\mathrm{H})$.

Altogether, these benefits show that opening the way to enforcing minority rights through collective procedures would contribute to bridging the gap between minority claims that rely on collective notions, and the individualist framework that most legal systems offer.

\section{COLLECTIVE PROCEDURES}

For the purposes of this article, 'collective procedure' refers to legal procedures before courts or other bodies tasked with the implementation of minority rights $^{30}$ in which a claim may be brought on behalf of a group defined therein, without requiring that all members of that group opt into the procedure. ${ }^{31}$ A procedure of this kind allows for claims to be aggregated, even when not all the victims participate in the action. Inevitably, such procedures raise the problem of absent parties and representation.

Class action in the United States is the most extensively explored type of collective procedure, but discussions in other jurisdictions, ${ }^{32}$ including that of the European Union, have also taken place over the past decade or so. ${ }^{33}$ This article broadly outlines what collective procedures do, but avoids detailed discussion of technical specificities. While technicalities ${ }^{34}$ may prove crucial for the success of procedural instruments, the deeper we go, the greater the need for specific contexts that cannot be explored here.

Therefore, the analysis is limited to a discussion of central elements that should be common to the implementation of all types of collective procedure. The goal is to show that any workable collective procedure that (also) covers minority claims will bring important benefits. The focus is further limited to racial, ethnic, national, linguistic and religious minorities, terms often used within the UN context. ${ }^{35}$

A collective procedure is a legal device that can be applied under certain conditions (the input side) and that may lead to the application of specific

\footnotetext{
30 This means that even where the article refers to litigation, all these other venues are also in mind.

31 This article does not deal with procedures that require opt-in or defendant-side groups; it also omits discussion on whether it is possible to leave a group (mandatory vs opt-out procedures).

32 For a global overview, see BT Fitzpatrick and RS Thomas (eds), The Cambridge Handbook of Class Actions: An International Survey (Cambridge University Press 2021).

33 D Fairgrieve and G Howells, 'Collective Redress Procedures - European Debates' (2009) 58 ICLQ 379.

34 Allocation of costs is one such area that plays an important role, especially in law and economics-based discussions around collective procedures.

35 International Covenant on Civil and Political Rights (adopted 16 December 1966, entered into force 23 March 1976) 999 UNTS 171 (ICCPR) art 27; Universal Declaration of Human Rights (adopted 10 December 1948) UNGA Res 217 A(III) (UDHR) art 2; Declaration on the Rights of Persons Belonging to National or Ethnic, Religious and Linguistic Minorities (adopted 18 December 1992) UNGA Res 47/135, art 2.
} 
provisions (the output side). On the input side, claims qualify for collective procedures under certain conditions. In the class action terminology, the requirements of numerosity, commonality, typicality and adequacy of representation should be assessed before one or more members of a class are allowed to bring a claim on behalf of all its members. ${ }^{36}$ Thus, claims should be sufficiently numerous to warrant triggering a collective procedure; ${ }^{37}$ they should have key elements in common that make aggregation meaningful; the initial claims should show features typical of the class as a whole; and representatives should demonstrate that they are in a position to speak on behalf of the entire group. On the output side, collective procedures require additional procedural guarantees, especially in ensuring that absent group members are represented fairly, and the way remedies are devised should also consider the group aspect.

Although the most established version of a collective procedure is to be found in the United States, similar attempts have been made in other jurisdictions. ${ }^{38}$ In fact, there are numerous ongoing efforts to provide more systemic legal responses to widespread violations. ${ }^{39}$

In the European Union, collective procedures are already available to victims of violations of consumer law, ${ }^{40}$ and the Commission has issued a recommendation that collective redress mechanisms be implemented in respect of a wide range of violations of rights granted under EU law. ${ }^{41}$ The European Law Institute and UNIDROIT have also published draft recommendations for a unified European collective action regulation. ${ }^{42}$

36 Federal Rules of Civil Procedure, Rule 23.

37 Note that numerosity is also a factor when deciding on a pilot judgment procedure before the European Court of Human Rights, see, for example, Lakatos v Hungary App No 21786/15 (ECtHR, 26 June 2018) para 86.

38 The article takes certain basic (but not evident) conditions for granted, such as a working rule of law system with an independent judiciary and legal rules largely following fundamental notions of equality. While courts can hardly be entirely free from biases against minorities when such biases are present in society as a whole, if they are too entrenched, they might block, in practice, all attempts at securing better minority rights enforcement. Widespread discriminatory patterns cannot be remedied through litigation alone; important commitment is required from outside the court system, especially from political decision-makers.

39 For an overview of problems and solutions for targeted international responses to mass claims, see HM Holtzmann and E Kristjánsdóttir, International Mass Claims Processes: Legal and Practical Perspectives (Oxford University Press 2007).

40 Directive on Representative Actions for Consumers (n 9). For an overview of the underlying debates, see Fairgrieve and Howells (n 33).

41 Recommendation (EC) 2013/396/EU of 11 June 2013 on common principles for injunctive and compensatory collective redress mechanisms in the Member States concerning violations of rights granted under Union Law [2013] OJ L201/60.

42 European Law Institute (ELI) - International Institute for the Unification of Private Law (UNIDROIT), 'From Transnational Principles to European Rules of Civil Procedure, Chapter [X]: Collective Redress (Draft)' (2018) < https://www.europeanlawinstitute.eu/fileadmin/ user_upload/p_eli/Projects/Unidroit_Materials/Trier_2018/WG_Parties_-_Draft_on_Collective_ Redress.pdf $>$; for a comparison of the proposal and the EU rules, see V Smith, 'Redress through Collective Actions in Europe: ELI/UNIDROIT and European Commission Proposals' (2019) 24 UnifLRev 1. 
National laws on collective procedures also exist, both inside and outside the European Union, ${ }^{43}$ for example, the collective procedural solutions in Commonwealth countries, including group litigation in the United Kingdom. ${ }^{44}$

In 1998 the filtering function of the Commission on Human Rights ended and the ECtHR became the place where individual complaints were considered. This led to a considerable backlog that, in turn, inspired the pilot judgment system set up in 2004. This mechanism is described as 'a means of dealing with large groups of identical cases that derive from the same underlying problem'. ${ }^{45}$ However, representative-type actions are still not recognised, and complaints can only be filed by those who are able to claim victim status. ${ }^{46}$

Compared to class actions, pilot judgments stop halfway, and fail to provide for a fully-fledged collective procedure that extends remedies to a group of claimants with comparable claims. This has resulted in criticism and a proposal that the European system should be brought closer to class actions. ${ }^{47}$ In a memorandum, the then president of the ECtHR, Jean-Paul Costa, described class actions as a new idea that 'can be explored immediately', to address the most pressing challenges affecting the Court's operation. $^{48}$ The merits of class actions have also been addressed in Strasbourg case law, including an argument for pilot judgments to be brought closer to class action judgments. ${ }^{49}$

The European Social Charter includes a collective complaints mechanism ${ }^{50}$ that can accommodate group claims, see for example, the various (successful) complaints filed by the European Roma Rights Centre (ERRC), the European Roma and Travellers Forum (ERTF) and other NGOs in this field. ${ }^{51}$ The Inter-

${ }^{43}$ For an overview, and an argument in favour, of class action type regulation in Europe, see CI Nagy, Collective Actions in Europe: A Comparative, Economic and Transsystemic Analysis (Springer Nature 2019).

44 See chapters, among others, on England and Wales, New Zealand and Australia in Fitzpatrick and Thomas (n 32).

45 European Court of Human Rights (n 10) 1.

46 One could cite as an exception, in a very specific field, challenges to secret surveillance programmes, such as in the Big Brother Watch case. Yet, even there, when considering victim status concerning the Upstream programme, the Grand Chamber relied on the fact that two of the applicants had had their communications requested by the Government Communications Headquarters. Big Brother Watch v United Kingdom App Nos 58170/13, 62322/14 and 24960/15 (ECtHR, 25 May 2021) paras 467-472.

47 Sainati (n 14) 158 for the criticism that the pilot judgment system is mainly focused on judicial economy and arguing, as a remedy, for bringing the regulation closer to class actions in the United States.

${ }^{48}$ J-P Costa, 'Memorandum of the President of the European Court of Human Rights to the States with a View to Preparing the Interlaken Conference' (European Court of Human Rights, 3 July 2009) 7 <https://www.echr.coe.int/Documents/Speech_20090703_Costa_Interlaken_ENG. pdf $>$.

49 Hutten-Czapska v Poland App No 35014/97 (ECtHR, 19 June 2006) partly concurring, partly dissenting opinion of Judge Zupančič.

50 'Collective Complaints' (n 11).

51 There are, in early 2021, three pending and ten processed complaints from ERRC. The ERTF filed three complaints that have been decided. The Equal Rights Trust also filed a complaint in a case where discrimination against the Roma was found. The European Commission of Social Rights found violations in all cases that have been decided. See the lists at $<$ https://www.coe.int/en/web/ 
American human rights system has famously dealt with collective claims, the most important of which are probably the Aloeboetoe ${ }^{52}$ and the Plan de Sanchez Massacre ${ }^{53}$ cases. In both instances, the Inter-American Court of Human Rights awarded remedies that were collective in nature to a group of applicants (families of seven individuals and hundreds of other individuals, respectively). The African human rights system has always placed a strong emphasis on collectivities. ${ }^{54}$ The post-apartheid constitution in South Africa specifically mentions the rights of a 'group or class of persons' to judicial relief, ${ }^{55}$ with case law specifically referring to links to 'the vulnerability of the people previously disadvantaged by apartheid'. ${ }^{56}$ The UN General Assembly's definition of victims includes those who have 'collectively suffered harm'. ${ }^{57}$ The International Criminal Court has a separate Victims' Trust Fund that targets larger groups of victims. ${ }^{58}$

What is also often forgotten is that the very idea of legal protection for minorities began with a group-based approach in interwar Europe. Mark Mazower reminds us that ' $[\mathrm{t}]$ he League of Nations came to stand for a system that ... accepted (perhaps thereby sometimes encouraging the creation of) minorities as collective entities'. ${ }^{59}$ We have come a long way since then, and there is no need to revert to the standards of a bygone era that was swept away by the failure to prevent another war. Be this the case, it does indicate that a focus on groups is not in itself alien to the European approach to the minority

european-social-charter/processed-complaints $>$ and $<$ https://www.coe.int/en/web/european-socialcharter/pending-complaints>.

52 Aloeboetoe et al $v$ Suriname (Reparations and Costs) IACtHR Series C No 15 (10 September 1993). For a short commentary, see S Davidson, 'Remedies for Violations of the American Convention on Human Rights' (1995) 44 ICLQ 405.

${ }^{53}$ Plan de Sánchez Massacre v Guatemala (Reparations) IACtHR Series C No 116 (19 November 2004).

54 African Charter on Human and Peoples' Rights (adopted 27 June 1981, entered into force 21 October 1986) (1982) 21 ILM 58 (African Charter) arts 19-24.

55 Section 38(c) of the Constitution of South Africa. For a discussion of some related constitutional questions, see T Broodryk, 'Class Action Certification and Constitutional Claims: The South African Case' (2020) 27 MJ 636. 56 ibid 643.

57 UNGA Res 60/147, 'Basic Principles and Guidelines on the Right to a Remedy and Reparation for Victims of Gross Violations of International Human Rights Law and Serious Violations of International Humanitarian Law' (21 March 2006) UN Doc A/RES/60/147, art 8. Article 14 of the Convention on the Elimination of All Forms of Racial Discrimination also foresees communications from 'groups of individuals'.

58 International Criminal Court, Rules of Procedure and Evidence (2013) Rule 98, paras 3 and 4. D Shelton and T Ingadottir, 'The International Criminal Court Reparations to Victims of Crimes (Article 75 of the Rome Statute) and the Trust Fund (Article 79)' (New York University Center of International Cooperation 1999). For an argument on how this should apply to larger groups of victims of aggression, citing calls for a separate international body for reparations, see S Darcy, 'Accident and Design: Recognising Victims of Aggression in International Law' (2021) 70 ICLQ 103, 117-19. See also E Kristjánsdóttir, 'International Mass Claims Processes and the ICC Trust Fund For Victims' in C Ferstman, M Goetz, and A Stephens (eds), Reparations for Victims of Genocide, War Crimes and Crimes against Humanity: Systems in Place and Systems in the Making (Brill Nijhoff 2009) 167-95.

59 M Mazower, 'Minorities and the League of Nations in Interwar Europe' (1997) 126 Daedalus 47,51 . 
question. The landscape shows that collective procedures primarily target groups that have dispersed claims and are for some reason considered vulnerable. This presumption generally holds true for minorities who are commonly defined by their non-dominant position. ${ }^{60}$

Mass reparations often follow large-scale violations and system changes and are often discussed in the transitional justice context. Many such remedies require special attention to violations experienced by minorities. What recent developments such as the Black Lives Matter movement have brought to the forefront, building on earlier accounts of majority biases, namely, systemic racism and microaggressions, is the experience of everyday injustice by minorities. This injustice leads to calls for a break with the past, and for transition, reparation and reform, akin to the mass reparations in the transitional context. It is thus not surprising that collective procedures invoked in transitions also seem applicable to minority claims.

In what follows, eight sets of benefits resulting from collective procedures are listed, while possible challenges are also addressed. Although the effects of collective procedures are discussed in separate sections, they are intrinsically linked and interdependent.

\section{A. Increasing the Availability of Remedies}

From a human rights perspective, collective procedures are not only important because they can further rights enforcement in general. Indeed, the efficacy of a legal remedy is not simply a policy question concerning better enforcement or a benefit of a good system of tort law. The failure to provide for effective remedies is not a mere inconvenience, an injustice or a moral failure, it is also a violation of a universal legal principle and a recognised human right. From a positive perspective, the provision of collective procedures can itself constitute the implementation of a human right: the right to effective remedies. ${ }^{61}$ International norms require States to provide adequate, effective remedy for various human rights violations, ${ }^{62}$ and the right to adequate remedy is also part of customary international law. ${ }^{63}$

It is safe to assume that barriers to accessing justice impede claims from disadvantaged sections of society disproportionately, thus many minorities are particularly affected. Not only can collective procedures act against this disparate overall effect, but they can also help to ensure that the enforcement of minority rights does not favour relatively privileged sections within

\footnotetext{
${ }^{60}$ See, for example, F Capotorti, 'Study on the Rights of Persons Belonging to Ethnic, Religious and Linguistic Minorities' (1979) UN Doc E/CN.4/Sub.2/384/Rev.1, para 568.

${ }^{61}$ See, for example, UDHR (n 35) art 8; ICCPR (n 35) art 2.

${ }^{62}$ For an overview, see D Shelton, Remedies in International Human Rights Law (Oxford University Press 2015).

${ }_{63}$ Case Concerning the Factory at Chorzów (Germany v Poland) (Merits) PCIJ Rep Series A No 17, 21.
} 
minority communities. Collective procedures extend remedies to entire groups of victims, regardless of who has brought the claim. Therefore, they may help legal systems to deliver on their promise of effective remedies and, ultimately, of equality.

The institutional aspect of the question is the ability of human rights fora to deliver on their ultimate goal of responding to violations: 'Devising a system of adequate reparation is a litmus test for human rights bodies' and courts' ability to respond adequately and effectively to mass violations.' ${ }^{64}$ Lutz Oette advises all such institutions to 'explore further the use of compensation schemes ... that have the potential to provide a measure of justice to all victims of mass violations'.65

\section{B. Collective Procedures, Minority Claims and Structural Disadvantage}

Parties responsible for violations often go unpunished simply because the resulting harm is diffuse. Certain tortfeasors have to pay, while others who cause damage that is too thinly spread among victims do not. Not enforcing claims that are individually too small to warrant a legal challenge leads to a denial of rights, a type of discriminatory underenforcement based on the incidental structure of violations.

Aggregation can effectively counter this inherent bias in the tort system. ${ }^{66}$ In the minority rights context, this can make claims against widespread but hardto-quantify - and, as a result, neglected-forms of cultural discrimination viable. Aggregation of seemingly minor (eg language-based) instances of discrimination might allow such claims to move forward and deter further violations through damages awards, even in the absence of an available injunctive relief. Aggregation in these cases is a precondition of enforcement, ie of the fulfilment of the right to remedy.

Aggregation is also beneficial because it can empower plaintiffs. Economies of scale may permit more investment in areas that are important for winning a case, such as legal representation, discovery and organisation. These features are acknowledged in the class action literature to the extent that public debates in the United States point to a resulting imbalance to the advantage of plaintiff classes. Indeed, concerns that excessive empowerment can lead to

64 Oette (n 7) 241.

65 ibid.

66 For the argument that the only way to allow for the private enforcement of small claims in European competition law is through class actions, with an overview of US, UK and other European regulations, see M Pakamanis, 'The Role of Class Actions in Ensuring Effective Enforcement of Competition Law Infringements in the European Union' (2016) 2 International Comparative Jurisprudence 122. For a similar argument: Z Juska, 'Obstacles in European Competition Law Enforcement: A Potential Solution from Collective Redress' (2014) 7 EJLStud 114; G Gaudin and F Weber, 'Antitrust Damages, Consumer Harm, and Consumer Collective Redress’ (2021) 12 JECL\&Pract 370. 
a flood of frivolous claims, have informed legislative ${ }^{67}$ and judicial ${ }^{68}$ moves to restrict the scope of application of class actions.

However, it is submitted that concerns around frivolous claims and unfair settlements in the United States do not apply in the context of human rights litigation in Europe, ${ }^{69}$ where litigation motivated by direct financial gains is not a defining factor. It is for this reason that excessive incentives for plaintiffs and their attorneys are discussed outside the human rights context. ${ }^{70}$ Furthermore, in the context of minority claims, the criticism that class actions over-empower plaintiffs can be reinterpreted simply as a move towards restoring balance. It is difficult to imagine how collective procedures could tip the scales 'too much' in favour of enforcing minority rights. Any proplaintiff bias would be one step towards redressing the overall prejudice of a legal system built on majority biases.

The NAACP Legal Defense \& Educational Fund argues that class actions 'offer remedies for civil rights violations in circumstances where individuals are unlikely to proceed on their own because they lack timely notice, have insufficient resources, or fear retaliation'. ${ }^{71}$ This might be of particular relevance in the minority context, where class actions can be used to vindicate rights and damages that are contrary to the established views within mainstream society. ${ }^{72}$

In a system in which only the particular individuals bringing the claim can obtain remedies, many victims in an underprivileged position will miss out. It might, for example, be particularly difficult to reach such victims to invite them to join as parties to litigation, or to obtain the necessary evidence to deliver individual justice for everyone. In areas such as 'prisoners' rights, school desegregation, and employment discrimination ... class actions have played a vital role. They have made it possible to afford relief to large numbers of persons who, realistically, could not have been parties to litigation. ${ }^{9} 3$ Similarly,

${ }^{67}$ Coffee cites the 1995 Private Securities Litigation Act as an example for when this served as an express motivation for legislation. JC Coffee, 'Reforming the Securities Class Action: An Essay on Deterrence and its Implementation' (2006) 106 ColumLRev 1534, 1534.

${ }^{68}$ See Resnik commenting on three key US Supreme Court cases: J Resnik, 'Fairness in Numbers: A Comment on AT\&T v. Concepcion, Wal-Mart v. Dukes, and Turner v. Rogers' (2011) 125 HarvLRev $78 . \quad{ }^{69}$ See, in the context of the ECtHR, Sainati (n 14) 184-5.

${ }^{70}$ In the European context, this fear motivated the limitation of representative actions to nonprofit entities; see Directive on Representative Actions for Consumers (n 9) art 4(3)(c).

71 'Brief for the NAACP Legal Defense \& Educational Fund, Inc. as Amici Curiae Supporting Respondents, AT\&T Mobility LLC v Concepcion, 131 S. Ct. 1740’ $3<$ https://www.naacpldf.org/ wp-content/uploads/brief.pdf $>$.

72 Judge Robert Carter argues that "in cases "seeking to vindicate novel rights in the face of majoritarian hostility, the very ability to proceed required the institution of a class action" because a "lone plaintiff" may be "extremely vulnerable to the pressure of intimidation".' ibid 16; quoting RL Carter, 'The Federal Rules of Civil Procedure as a Vindicator of Civil Rights' (1989) 137 UPaLRev 2179, 2186.

73 J Greenberg, 'Civil Rights Class Actions: Procedural Means of Obtaining Substance' (1997) 39 ArizLRev 575, 585. 
William $\mathbf{J}$ Aceves argues for the benefits of the collective approach to human rights litigation and the help it potentially offers to the least well-off. ${ }^{74}$

With these concerns in mind, it should be acknowledged that collective procedures, as they are understood here, are neither the sole alternatives to individual litigation nor necessarily superior to other procedures. Sometimes representative action or public interest litigation - where organisations litigate on behalf of wider groups or interests without the requirement to legally represent plaintiffs - or centralised enforcement through State or quasi-State bodies could offer vulnerable victims better shielding from further victimisation.

Where collective procedures do offer more is in providing guarantees of adequate representation, and legal recognition of a group and its suffering, with the empowerment that brings with it. The procedural recognition of a collectivity can help minorities gain leverage in political struggles. If we see rights litigation as part of a broader strategy for political emancipation, a class action could embody a cause, creating an issue that all concerned can relate to: 'for individuals who have experienced discrimination and other civil rights violations, ... association for litigation may be the most effective form of political association'. ${ }^{75}$ This potentially goes beyond strictly symbolic benefits, and links back to the empowerment argument. Individual litigation risks reinforcing existing inequalities and organisational disadvantages. Luc Walleyn compares successful Holocaust claims to the lack of resolution 'for the less organised Roma community'. ${ }^{76}$ Collective procedures will not make such differences disappear, but they can make up for some of the organisational disadvantages.

Furthermore, the recognition of a group in the proceedings may be more than merely symbolic since it may contribute to the remedial goal itself: 'The class certification process, as well as the public and media attention that class actions generate, broadens awareness about and expand[s] participation in civil rights and other litigation.' 77 Collective procedures, under this wider reading, also contribute to the empowerment of minority groups.

\section{Collective Procedures and Minority Claims with Collective Dimensions}

Existing minority rights guarantees that focus exclusively on individual rights often fail because they miss the collective element inherent in many minority

74 Aceves (n 13) 354.

75 NAACP v Button 371 US 415, 431 (1963), cited 'Brief for the NAACP Legal Defense \& Educational Fund, Inc. as Amici Curiae Supporting Respondents, AT\&T Mobility LLC v Concepcion, 131 S. Ct. 1740' (n 71) 25.

76 L Walleyn, 'The Prosecution of International Crimes and the Role of Victims' Lawyers' in Ferstman, Goetz and Stephens (n 7) 363.

77 'Brief for the NAACP Legal Defense \& Educational Fund, Inc. as Amici Curiae Supporting Respondents, AT\&T Mobility LLC v Concepcion, 131 S. Ct. 1740’ (n 71) 16. 
rights claims. ${ }^{78}$ Many minority rights violations target minorities as groups, an aspect often overlooked once the resulting claims are transformed into legal claims. While the individualist approach can provide important safeguards by constraining collective overreach and the possible oppression of individual group members, there are cases where the limitations of individualism are overly constraining and act as a barrier to legitimate claims.

As background, there is the Western State that treats other, potentially competing, collective entities with suspicion or outright hostility, something that Gerald Frug calls 'a continuing liberal unwillingness to tolerate an intermediate entity that appears to threaten the interests of both the state and the individual'. ${ }^{79}$ Hans Kelsen also identifies this seemingly 'insoluble conflict' between the individual and the community, arguing that it is simply an ideology in the struggle of certain interests to resist containment by a collective system' ${ }^{80}$ Jacob $\mathrm{T}$ Levy considers that there exists an irreconcilable conflict between the rationalist and the pluralist traditions of liberal thought, the former undermining the recognition of intermediate groups, the latter endangering individual liberty. ${ }^{81}$ For the purposes of this argument, it is enough to acknowledge that some group claims that do not threaten the State or the individual are lost as a result of the individualist filter, but could be 'saved' by collective procedures, without interfering with a system built on individual guarantees.

Daryl Levinson describes how law tends to neglect social context and to imagine 'atomistic individuals who interact only at the point of a discontinuous event'. ${ }^{82}$ The human ideal of our legal tradition is an independent actor, largely free from outside interference. On the other hand, States are very much entrenched actors in law and politics, so much so that there are accounts that justify the protection of minority rights by the need to provide balance. ${ }^{83}$ Collective procedures are, on this reading, a welcome addition towards restoring the balance in what is still an era of national(ising) States and filling the void between States and individuals.

Acceptance of the idea of the individualist and statist biases described are not essential in order to recognise the need for collective procedures. It is sufficient to accept that in certain cases individualist selectivity may turn into a distinctive ignorance of what cannot be readily presented as a sum of individual rights, claims or interests.

\footnotetext{
${ }^{78}$ W Kymlicka, Multicultural Odysseys: Navigating the New International Politics of Diversity (Oxford University Press 2007).

79 GE Frug, 'The City as a Legal Concept' (1980) 93 HarvLRev 1057, 1116.

${ }^{80} \mathrm{H}$ Kelsen, Introduction to the Problems of Legal Theory: A Translation of the First Edition of the Reine Rechtslehre or Pure Theory of Law (BL Paulson and SL Paulson trans, Clarendon 1992) 51-2. $\quad 81$ JT Levy, Rationalism, Pluralism, and Freedom (Oxford University Press 2015).

82 DJ Levinson, 'Framing Transactions in Constitutional Law' (2002) 111 YaleLJ 1311, 1313.

83 P Macklem, 'Minority Rights in International Law' (2008) 6 ICON 531. For the argument that claims by minority groups or 'sub-state national societies' are a reflection of contemporary radical reconfigurations of the models of authority, see S Tierney, 'Reframing Sovereignty? Sub-State National Societies and Contemporary Challenges to the Nation-State' (2005) 54 ICLQ 161.
} 
Walleyn argues that '[c]ollective forms of reparation are often a logical approach to offer redress to traumatised communities' and that individualisation risks that 'no compensation is to be paid to families who were totally exterminated'. ${ }^{84}$ Consider the question of how to capture cultural loss, central to many minority cultures. Applicants in the Plan de Sanchez Massacre case sought remedies for material and immaterial losses after the extermination of members of an indigenous community and cultural losses due to the killing of the tribe's elders. Members of the Maya-Achí tribe were raped, tortured and assassinated by armed forces and civil patrols as part of a massacre on 18 July 1982. In addition to public (and publicised) acknowledgment, the Inter-American Court of Human Rights provided remedies, including pecuniary damages of $\$ 5,000$ and non-pecuniary damages of $\$ 20,000$ per person; funds for a commemorative chapel; health institutions (including a local health centre); a special psychological and psychiatric programme benefiting the victims; adequate housing; a Statefinanced study of Maya-Achí culture; maintenance and improvement of the road system; a sewage and water supply system; and schooling with bilingual teaching personnel. ${ }^{85}$

Collective procedures also mean that minority groups will be recognised on a per case basis, ie the relevant group in any particular case is simply the group of victims of the violation in question. This avoids the complexities involved in according legal recognition to minority groups, which involves determining what constitutes a single minority group as opposed to separate or loosely federated groups; how stable the group's boundaries are; and who precisely belongs to it. Some groups emerge largely as a response to violations, while others may have been pre-existing communities. Legal recognition within the limits of one procedure and one set of claims ('procedural recognition') can offer a better match between victims and violations.

Procedural recognition may serve not only as a makeshift solution in the absence of group recognition but may even be a superior option to rigid definition of what constitutes a group. Consider cases where proxies like religious organisations or even States are used in claims concerning largescale violations - a situation that may be far less satisfactory than recognition of a group of victims in a collective action.

The mismatch between victim group and assigned entity may become intolerable, and the lack of an adequate claimant may make an otherwise valid claim unenforceable. One example is the genocide case of Bosnia and Herzegovina $v$ Serbia and Montenegro. Ultimately, the International Court of Justice avoided the issue of compensation in this case. ${ }^{86}$ However, had it not

${ }^{84}$ Walleyn (n 76) 363.

${ }^{85}$ Plan de Sánchez Massacre v Guatemala (Reparations) (n 53).

86 Application of the Convention on the Prevention and Punishment of the Crime of Genocide (Bosnia and Herzegovina $v$ Serbia and Montenegro) [2007] ICJ Rep, paras 461-462. 
done so, compensation would have been paid to the claimant State of Bosnia and Herzegovina with no guarantee it would benefit victims. This case also illustrates that it is problematic for the defendant group not to be identified, as compensation would have been paid by the State of Serbia and Montenegro, meaning that ethnically non-Serbian citizens residing and paying taxes in Serbia would have contributed to the compensation payment.

On another occasion, the ECtHR was faced with a different problem of mismatch when deciding on remedies for a governmental decision causing detriment to an orthodox church. The Court awarded damages to the Church 'to be paid to [the Church] leader at the relevant time, for the benefit of the religious community' 87 and dismissed related claims by individual worshippers. The Court argued that all members' claims were subsumed under the 'collective' claim filed by the comprising Church: 'since the leadership directly affected by the violation ... claimed compensation for the non-pecuniary damage suffered by the religious community it leads, there is no room for separate awards to the six individual applicants' ${ }^{88}$ The judgment added that damages for similar violations of religious rights are, in the Court's case law, due 'only to the ousted leaders or members of governing bodies' 89 Judge Kalaydjieva noted in her dissent that this effectively amounts to a "“class action" approach'. ${ }^{90}$ In fact, a class action-like collective procedure would have allowed all the victims to receive compensation: it would have been possible to define two sub-classes and design the damages accordingly. ${ }^{91}$

The leading international minority rights case, Lovelace $v$ Canada, ${ }^{92}$ concerned a situation in which a minority community had violated the rights of one of its members. The minority community responsible for the violation was not represented (unless we count the majoritarian representation of the central government). In this case, the presence of the collective party would have made no difference to the outcome, and the remedy sought (an end to the violating practice) did not require a complex approach. Yet, if women in a similar situation had been asking for compensation for harm they had suffered (denial of residency, housing and a series of other benefits, in addition to non-material damages), a clearer procedural structure (victim group as plaintiff and the tribe as defendants) would have allowed responsibility to play out legally.

The recent Okpabi case from the United Kingdom, where group litigation is available, shows the potential and flexibility of group actions. The central point of contention is the court's jurisdiction to hear a claim brought against a UK parent company for environmental damage and human rights abuses

\footnotetext{
${ }^{87}$ Holy Synod of the Bulgarian Orthodox Church (Metropolitan Inokentiy) and Others $v$ Bulgaria App Nos 412/03 and 35677/04 (ECtHR, 16 September 2010) para 39.

88 ibid para 45.

90 ibid, partly dissenting opinion of Judge Kalaydjieva.

91 For more on matching victim groups and damages, see Section II.E below.

92 Sandra Lovelace v Canada, Comm No R.6/24, UN Doc Supp No 40 (A/36/40) at 166 (1981).
} 
allegedly committed by one of its foreign subsidiaries in a foreign jurisdiction. However, it is the composition of the claims and the plaintiff side that merit attention here. The first set of claims is part of a group action brought by 20 named claimants, among them the 17 members of the Council of Chiefs of the Ogale Community, including Okpabi, their king. They make claims not only in their personal capacity, but also 'on behalf of the people of the Ogale community, ${ }^{93}$ 'a Nigerian farming and fishing community of approximately 40,000 individuals in Rivers State, Nigeria'. ${ }^{94}$ In another set of claims litigated in the same proceedings, individual claims are presented by '2,335 individuals who live in the Bille Kingdom, a remote riverine community in Rivers State, Nigeria'. ${ }^{95}$ The case demonstrates how collective and individual claims can be combined to match the immense complexity of violations and harms.

\section{Collective Procedures and Minority Claims Concerning Systemic Harm}

Discrimination that is only apparent from a broader perspective might be impossible to prove with sufficient certainty if only strictly individual evidence is accepted. Without being forced to see the overall context or the pattern of decisions that have a discriminatory impact, underlying claims may be dismissed as non-litigable political claims that fall outside equality guarantees provided under law. That courts ought to consider social context has been a largely uncontroversial view ever since the sweeping challenge to formalism by legal realism in the USA. More recently, critical legal studies have emphasised the role of the oft-hidden social vision of the law. For example, in considering accident law, Henry J Steiner argues that courts 'increasingly understand accidents not as random events first linking a defendant and victim, but as a serious problem of systematic incidence' ${ }^{96}$

The very fact of aggregation may show a different picture, helping the plaintiffs use evidence that would otherwise be rejected as irrelevant statistical data about issues outside the scope of the litigation. Showing the entire picture, or a larger part of it, might in itself tilt the scales: 'It's difficult for an individual to persuade a jury that he's telling the truth, [but] when you have 50 or 60 or 100,000 people coming in, ... it really changes the balance of power. It's like having a union.' ${ }^{97}$ There are many types of claims in which only statistical evidence can come close to offering conclusive proof of the victimisation of minorities.

93 Okpabi \& Ors v Royal Dutch Shell Plc \& Anor [2017] EWHC 89 (TCC) (26 January 2017).

94 Okpabi \& Ors v Royal Dutch Shell Plc \& Anor [2021] UKSC 3.

${ }^{96}$ HJ Steiner, 'Justification and Social Vision in Common Law Change: The Case of Modern Accident Law' (1983) 15 (unpublished manuscript, on file with author).

97 Attorney William Claiborne quoted in P Karlsgodt, "Class Certification Means "Everything" for Baltimore Arrestees' (ClassActionBlawg.com, 24 March 2009) <https://classactionblawg.com/ 2009/03/23/class-certification-means-everything-for-baltimore-arrestees/>. 
Part of the problem can be remedied by accepting evidence that goes beyond the case at hand. A pertinent illustration of how that is relevant is to consider the restrictive American approach. The fact that a black defendant in a criminal trial was convicted by a jury that had no black jury members might not prove much; however, if precisely the same pattern is repeated and demonstrated across hundreds upon hundreds of cases without, or almost without, exception, then the court's assessment might be different. If a court rejects statistical evidence, for example, because it rejects disparate impact assessment, ${ }^{98}$ it will become hard to prove that the lack of black jurors in a case is a result of a discriminatory practice rather than an isolated instance. ${ }^{99}$ When Southern racist policies switched to non-written rules of exclusion, it became easy to avoid the conclusion that discrimination was demonstrably present in individual cases, as in jury selection cases or voting rights litigation. ${ }^{100}$ It is easier to establish a discriminatory practice through a class of cases rather than isolated instances which can be explained away as having non-systemic causes. This can work to the detriment of minority interests, which are especially vulnerable to individualisation: if presented and assessed in isolation, one case might not prove the pattern that persuasively shows the existence of discrimination.

Most European legal fora are more open to the type of broader evidence that can uphold claims of systemic discrimination. However, the way claims are framed can reflect narrow readings of violations, to the detriment of claims related to systemic violations. Control over the right 'framing', as Daryl Levinson calls it, will decide what counts as violation and as adequate remedy. Examining violations as resulting from isolated transactions can sink minority calls for remedial measures:

the model of transactional harm offers no guidance as to how to frame constitutional transactions and places no limits on aggregation over time, scope, and group. Because the model relies on such a thin and simplistic understanding of undesirable government behaviour - discrete instances of individualized harminfliction - it simply lacks the conceptual resources to generate a normative theory of how harms and benefits ought to be framed against the background of the continuous relationship between government and citizens. ${ }^{101}$

The judicial approach that grants heightened protection to some groups and classifications is also based on a collective assessment of social and political factors. Programmes based on positive discrimination and affirmative action also follow collective assessment to justify individual differentiation. It is true

98 As in Washington v Davis 426 US 229 (1976).

99 As in McCleskey v Kemp 481 US 279 (1987), see BL Garrett, 'Aggregation and Constitutional Rights' (2012) 88 NotreDameLRev 593, 624-5.

${ }^{100}$ For an overview of the historical context, see MJ Klarman, From Jim Crow to Civil Rights: The Supreme Court and the Struggle for Racial Equality (Oxford University Press 2008).

101 Levinson (n 82) 1374-5. 
that the nature of political and legal decision-making is different and arguments for more inclusive processes in the political arena do not readily translate into the judicial arena. ${ }^{102}$ In the minority field, however, the argument can rely on an established claim that judicial protection is most legitimate for groups that are systematically disadvantaged by political processes primarily built on majoritarian decision-making. ${ }^{103}$

By aggregating harms and benefits, on the procedural level, we switch 'the unit of constitutional analysis from the net welfare of an individual, to, at the limit, the net welfare of society as a whole'. ${ }^{104}$ What makes class action special in this context is that it provides a powerful device through which the plaintiffs can create the frame, or present the relevant group, which can then influence the judgment of the substantial claim. As a result, the 'framing', which is usually hidden, will become part of the litigation and part of the problem that the parties and the court will need to address in a transparent process.

The ability to present context can work in a manner akin to shifting the burden of proof for every individual case in the class, like the relevant rule of the EU's Racial Equality Directive. ${ }^{105}$ Even with strong anti-discrimination standards of evidence in place, allowing groups of claimants to litigate makes it more likely that courts will see the wood for the trees.

Indigenous groups have been making land rights claims all over the world. The attempts by the Sami in Norway and Sweden provide for a more positive storyline than, for example, the Aboriginal land cases in Australia. Claims by the Sami were in limbo for a considerable time because the indigenous group could not produce the type of evidence that is normally required to prove land rights, ie official, State-certificated documents. It was impossible for the Sami to meet these requirements because their ownership is not a result of State-issued title; rather, it survived despite the expansion of the State. In Norway, the Supreme Court adopted a standard sensitive to the peculiarities of the case and accepted historical evidence in lieu of official documents attesting property rights. The Court reversed the burden of proof, stating that it was well known that Sami herders had long been present in the area, so it was not Sami ownership that had to be proven but the claim that later rights extinguished it. ${ }^{106}$ Without this move away from the traditional standards of the legal system, these minority claimants would have found themselves not only without legal

\footnotetext{
102 A sceptical account based on the UK context: C Harlow, 'Public Law and Popular Justice' (2002) 65 The Modern Law Review 1.

103 United States v Carolene Products Company 304 US 144, 152, fn 4 (1938) and JH Ely, Democracy and Distrust: A Theory of Judicial Review (Harvard University Press 1980).

104 Levinson (n 82) 1371.

105 Council Directive 2000/43/EC of 29 June 2000 implementing the principle of equal treatment between persons irrespective of racial or ethnic origin [2000] OJ L 180/22 (Racial Equality Directive).

106 Jon Inge Sirum v Essand Reindeer Pasturing District and Riast/Hylling Reindeer Pasturing District, Norwegian Supreme Court (2001) No 4B/2001.
} 
protection, but in a situation where the law is in fact mobilised to deny their long-standing usage rights. Since the precedent set by the Norwegian Supreme Court, the Swedish Supreme Court has adopted a somewhat similar standard. ${ }^{107}$

The impact of a collective, historical assessment is also reflected in the approach taken by the ECtHR in the leading Roma case, DH and Others $v$ Czech Republic (also dubbed the 'European Brown $v$ Board of Education'), ${ }^{108}$ where the finding of a violation (school segregation) was preceded by an overview of a long list of documents describing the general plight of European Roma. ${ }^{109}$

It is essential to stress the importance of legal culture in assessing claims that are related to culture and cultural rights. This article has argued that there are cultural losses that are difficult to identify at the level of the individual, but that can easily be demonstrated on the level of a tribe or other community. This aspect is especially important if we consider that Western legal systems, especially when applied to non-Western cultures, tend to be selective and filter out interests that might be pressing for these cultures yet are not valued when viewed through the lens of law. ${ }^{110}$ The problem is most apparent when we consider claims resting on less individualistic notions that underpin many indigenous claims. Reassessing the individualistic approach of law allows us to uncover hidden assumptions inherent in the way litigation is set up in civil procedural rules, ${ }^{111}$ and in adjudication generally. A collective procedure may be a powerful tool for addressing these inherent obstacles.

\section{E. Collective Procedures and Damages Better Reflecting Patterns of Violations}

Human rights violations require effective and adequate remedies, but it is not always clear what types of remedies are effective or adequate. The most common remedy is monetary compensation to those harmed, but there are cases where the defendant is obliged to do, or to cease doing, something. In the case of an injunction, as when challenging the constitutionality of certain provisions and practices, the identity of the plaintiffs might be unimportant: a

\footnotetext{
107 The Swedish Supreme Court held, in a 2020 judgment, that a Sami community held the right to hunt and fish 'on the basis of the historical use of the land since time immemorial'. Case No T 853-18, Decision of 23 January 2020 (Högsta Domstolen [Swedish Supreme Court]) para 227, as cited in E Hofverberg, 'Sweden: Supreme Court Recognizes Sami Indigenous Group's Exclusive Right to Confer Hunting and Fishing Rights in Sami Area' (Library of Congress, 2020) <www.loc. gov/law/foreign-news/article/sweden-supreme-court-recognizes-sami-indigenous-groups-exclusiveright-to-confer-hunting-and-fishing-rights-in-sami-area/> (quote from the latter).

${ }_{108}$ Qualifying the parallel: J Greenberg, 'Report on Roma Education Today: From Slavery to Segregation and Beyond' (2010) 110 ColumLRev 919, 940.

109 DH and Others v the Czech Republic App No 57325/00 (ECtHR, 13 November 2007) Part III.

110 What is meant by 'Western' here is the dominant approach described as 'egalitarian individualism' in Freeman (n 22) 25.

111 BG Garth, 'Studying Civil Litigation Through the Class Action' (1987) 62 IndLJ 1.
} 
single plaintiff representing a larger group can litigate and may have the given policy eliminated (eg ending racial segregation in a school system).

A document adopted by the UN General Assembly in 2005 lists three types of remedies that victims are entitled to: access to justice, reparation and access to information. Under reparation, the document lists restitution, compensation, rehabilitation, satisfaction and guarantees of non-repetition. ${ }^{112}$ Assessing these from the point of view of groups (comprising all those who have suffered legally cognisable violations), compensation is decidedly individualoriented in that it is difficult to conceive of payments without identifying the entitled payees. ${ }^{113}$ For restitution, it is possible to implement measures that go beyond individual plaintiffs and thus address a wider class of victims. Nevertheless, most judicial remedies apply only to those who are parties to a case. With rehabilitation, satisfaction and restitution, it is easier for remedies to go beyond the plaintiff group, by rehabilitating or apologising to an entire group of victims. When it comes to guarantees of non-repetition, policy changes most often radiate out more broadly.

When examining remedies from a procedural perspective, the problem of collectivities does not arise everywhere. Certain remedies are likely to be collective in nature, with a radiating effect going beyond those directly involved in the lawsuit, regardless of the underlying procedure or the number of plaintiffs: an apology can be addressed to large groups without naming members and guarantees of non-repetition can include institutional reform with an impact on bystanders. Where the problem of individualisation is most pronounced is compensation, or individual payments to victims.

This article argues for the availability of collective procedures and their benefits for minority rights. However, the fact that certain claims could or should be dealt with in an aggregate fashion does not mean that individualisation is necessarily excluded, for example, it might remain with regard to the distribution of remedies to members of the group. Under collective procedures, individual remedies may coexist with collective remedies in a way that is not possible in individual actions. Courts can also design mechanisms to deal with a high volume of cases, assuring conformity to all victims. Statistical sampling or the use of random sampling, possibly involving subcategories, could address this issue, as indeed happened with regard to the claims of torture victims in the Marcos litigation, where the Court

112 UNGA Res 60/147, 'Basic Principles and Guidelines on the Right to a Remedy and Reparation for Victims of Gross Violations of International Human Rights Law and Serious Violations of International Humanitarian Law' (n 57) arts 11 and 19-23; see also D Shelton, 'The United Nations Principles and Guidelines on Reparations: Context and Contents' in K Feyter et al. (eds), Out of the Ashes: Reparation for Victims of Gross and Systematic Human Rights Violations (Intersentia 2005).

113 An exception could be cy-près payments, where courts try to identify a beneficiary as close as possible to the victims, for example, a foundation that helps people that have suffered similar violations. 
created five categories for statistical random sampling. ${ }^{114}$ The estate of the former dictator "was found specifically liable to a class of ten thousand Filipinos and twenty-three named plaintiffs for torture, summary execution, disappearance, and prolonged arbitrary detention'. ${ }^{115}$ What makes the procedures interesting for our purposes is the way they dealt with the enormous complexity of the resulting claims that could have undermined the entire procedure. ${ }^{116}$

The normal procedure would have been to have waited for legislative or executive action to draw up a scheme for the determination and distribution of funds. However, the Court came up with its own procedure. Based on expert testimony, District Judge Manuel Real determined that a sample of 137 would yield 95 per cent accuracy regarding the 9,541 claims. ${ }^{117}$ Of these, ' 67 were torture victims, 52 were execution victims and 18 were disappearance victims.' 118 Based on a standard established by Judge Real, a court-appointed Special Master considered various factors (eg in the case of torture: the methods of physical torture, mental abuse, the length of abuse and detention, the resulting injuries and losses, and the victim's age). ${ }^{119}$ Statistical sampling thus allowed the Court to balance the interest of maintaining consistent standards applied through a unified procedure with the goal of individualisation. The case also shows that defining subsets of claims (or subclasses) within the broader group of claims and victims can facilitate remedies that better match the impact of violations.

The availability of a range of remedies is a great leap forward from the individualised remedies that are more usually associated with rights violations. Lump sum compensation, together with other collective remedial measures, can address the effects of violations more broadly. More generally, 'injuries caused by public law violations frequently are intangible, symbolic and difficult to measure', which affects judicial remedies. ${ }^{120}$ Collective procedures enable courts to adopt similar schemes in response to the complex effects of large-scale violations. The ECtHR relied on a similar form of partial

114 In re Estate of Marcos (Human Rights Litigation) 910 F Supp 1460, 1464-7 (D Haw 1995); Hilao $v$ Estate of Ferdinand Marcos 103 F3d 767, $782-4$ (9th Cir 1996). For an overview of the aspect considered here, random sampling, from the point of view of the Special Master, see S Schreiber and L Weissbach, 'In Re Estate of Ferdinand E. Marcos Human Rights Litigation: A Personal Account of the Role of the Special Master' (1998) 31 LoyLALRev 475.

115 RG Steinhardt, 'Fulfilling the Promise of Filartiga: Litigating Human Rights Claims against the Estate of Ferdinand Marcos' (1995) 20 YaleJIntl L 65, 65-6 The consolidation of cases followed the Multi-District Litigation, which is an important tool for aggregating cases, but one that cannot be discussed here.

${ }^{116}$ For criticism of this aspect of collective procedures, see RH Trangsrud, 'Mass Trials in Mass Tort Cases: A Dissent' (1989) 1989 UIllLRev 69; DL Rhode, 'Class Conflicts in Class Actions' (1982) 34 StanLRev 1183.

117 In re Estate of Marcos (Human Rights Litigation) (n 114) 1464-5. $\quad 118$ ibid 1466.

119 ibid.

120 SP Sturm, 'A Normative Theory of Public Law Remedies' (1990) 79 GaLJ 1355, 1378, fn 126. 
individualisation when deciding on moral damages for victims of HIVcontaminated transfusions, awarding damages of either EUR 20,000, 25,000 or 30,000 in 364 individual cases. ${ }^{121}$

While individualisation is possible in group litigation, courts may nonetheless be reluctant to allow such litigation to proceed if they consider that the individual variation between victims is too great. This was a major blow to gender pay gap litigation in the United States, where, in 2011, the argument of managerial discretion when determining individual wages sank a class action claim that had been based on statistical evidence of discrimination. ${ }^{122}$ Courts can easily present requirements for individualisation that make it impossible to certify a class, as every individual claim in the victim group is different. Even if plaintiffs have been subject to the very same policy, the actual harm, the evidence, the length, the timing and several other circumstances might differ. On the other hand, there is a common core element, namely the policy that could be litigated across the class, presenting each case in a unified action. We have also seen how variation within the group of claims and victims can be considered in a collective procedure. The willingness of courts to consider such responses to violations is especially important where enforcement through isolated lawsuits is not viable.

It is often the complex interplay between political and legal responses to widespread violations that leads to the compensation of larger groups. The combined effects of fact finding and litigation, and public discussions and government response can be seen in the Canadian regime set up to respond to Indian Residential School cases, in which around 150,000 native children were forcibly removed from their families between 1879 and $1986 .{ }^{123}$ In similar cases, collective procedures can help present the broad scope of the claims and push for a comprehensive response.

\section{F. Collective Procedures and Procedural Safeguards for Adequate Representation}

A common argument against collective procedures is the problem of representation. It is true that the question of who can represent whom is an important aspect of collective claims, given the internal diversity of groups

121 DA and Others $v$ Italy App Nos 68060/12, 16178/13, 23130/13, 23149/13, 64572/13, 13662/ 13, 13837/13, 22933/13, 13668/13, 13657/13, 22918/13, 22978/13, 22985/13, 22899/13, 9673/13, 158/12, 3892/12, 8154/12 and 41143/12 (ECtHR, 4 July 2016) para 209 and Annexes.

122 Wal-Mart v Dukes 564 US 338 (2011). But see later efforts: U.S. Equal Employment Opportunity Commission, 'Walmart, Inc. to Pay \$20 Million to Settle EEOC Nationwide Hiring Discrimination Case (Press Release)' (10 September 2020) <https://www.eeoc.gov/newsroom/ walmart-inc-pay-20-million-settle-eeoc-nationwide-hiring-discrimination-case>.

${ }^{123}$ M Moran, 'The Role of Reparative Justice in Responding to the Legacy of Indian Residential Schools’ (2014) 64 UTLJ 529, 531. 
and interests of members. ${ }^{124}$ It will be argued that this is an issue common to many claims, not only in a collective procedural setting, and that collective procedures have built-in judicial guarantees.

Probably the most contested element of collective procedures is the seeming disregard for a traditional element of court procedures: party autonomy or the principle that all parties must be present or represented in a case, or that they have the right to have their 'day in court' when a judge considers claims that concern them. ${ }^{125}$ Framing the issue in this way, however, misrepresents the nature of the problem. The real difference does not lie between collective procedures that disregard the day-in-court ideal and individual litigation that respects this rule, but between judgments with less or more external impact, between courts that try to consider the extra-party impact of their decisions and those that disregard this effect. One litigant may challenge a discriminatory practice in an individual case, and when this practice is eliminated, a wider group or even society as a whole may feel the consequences. Remedies directly aimed at policy changes and deterrence are inherently more open and can go beyond the plaintiffs' concerns. Forwardlooking remedies seek change directly, mostly through injunctions, with a high potential for impact on non-parties. If it is ordered that a discriminatory practice should be terminated, the order will have an impact on people not represented in the case.

Establishing liability and applying certain standards of negligence always have a systematic effect on future behaviour because norms and their applications are (ideally) general. In this sense, all judgments are collective, because they provide defendants with an indication of how similar cases are likely to be decided in the future, and thus how defendants should adjust their behaviour to avoid incurring further liability. Taking the UN typology cited earlier, ${ }^{126}$ externalities may be present in rehabilitation, satisfaction and guarantees of non-repetition. The deterrence effect inherent in compensation also means that non-parties are likely to feel the effects of the judgment. While this 'radiation' is more or less pronounced, depending on the case, what we see is a structural violation of the 'day-in-court' requirement: those who are not parties to the case see their interests being litigated without actually being represented themselves.

In this sense, the collective approach is better, not worse, at considering individual differences, intra-group variation and possible internal divisions. However, even if we establish the move to accept interests as the ground for

124 G Gilbert, 'Individuals, Collectivities and Rights' in N Ghanea-Hercock and A Xanthaki (eds), Minorities, Peoples, and Self-Determination: Essays in Honour of Patrick Thornberry (Martinus Nijhoff Publishers 2005) 146.

125 For a good summary of the dilemmas of representation regarding class action, see Fiss (n 25).

126 UNGA Res 60/147, 'Basic Principles and Guidelines on the Right to a Remedy and Reparation for Victims of Gross Violations of International Human Rights Law and Serious Violations of International Humanitarian Law' (n 57). 
claim-making, as opposed to individual decisions to litigate, we should address the problem of the diverging interests of victims. ${ }^{127}$ Under US class action practice, it is also possible to identify sub-classes with differing sets of claims and interests. In a school desegregation case, a primary interest for former students might be in receiving compensation, while prospective students might be more interested in ending segregation, and current students and the local community might have an interest in both. A court in a collective procedure is better suited to designing remedies that mirror this complexity and to determining whether legal representation is fair to all victim groups.

Consider the case litigated by a minority Jewish community after France refused to recognise the right to maintain kosher slaughterhouses outside the one and only recognised Jewish association. The majority in the Strasbourg court decision did not find a violation, effectively forcing a minority within a minority to adhere to the rules of a religious body (including paying them a tax per kilo of beef sold) that they specifically refused to belong to. ${ }^{128}$ In this case, the rigidity of the (once-and-for-all) political recognition translated into exclusivity. Judicial recognition of a group as part of a collective procedure allows for less sweeping decisions that look at the specific claim and only recognise the group in relation to that.

\section{G. Collective Procedures, Remedies and Improved Deterrence}

Empowerment may be transitory if rights are not backed up with material guarantees. The key debate in political philosophy is about the need to focus on recognition as well as redistribution. ${ }^{129}$ Collective procedures help both: the recognition of groups and their sufferings in a legal procedure may be part of a symbolic remedy, while aggregation helps minorities extract compensation on a larger scale. The latter may help in making up for a key deficiency of minority rights guarantees: the lack of regard for material resources, which could cripple the effective enjoyment of rights and render the right to maintain minority institutions meaningless. As demonstrated by the Plan de Sanchez Massacre case, funding can be part of a comprehensive remedial package.

The breadth of remedies has wider social and regulatory consequences. Without aggregation, society is less just and less safe because 'eliminating the risk of liability for aggregated civil rights violations means that some number of those injuries will remain unredressed'. ${ }^{130}$ Allowing compensation

\footnotetext{
127 See, for example, Freeman arguing that '[m]embership of groups can be fluid and uncertain'. Freeman (n 22) 39.

128 Cha'are Shalom Ve Tsedek v France App No 27417/95 (ECtHR, 27 June 2000).

129 N Fraser, A Honneth and J Golb, Redistribution or Recognition? A Political-Philosophical Exchange (Verso 2003). 130 'Brief for the NAACP Legal Defense \& Educational Fund, Inc. as Amici Curiae Supporting Respondents, AT\&T Mobility LLC v Concepcion, 131 S. Ct. 1740' (n 71) 4 .
} 
claims to go forward in cases that would otherwise be thrown out also serves the goal of prosecuting defendants who would otherwise not be made liable, effectively triggering a deterrence effect. The more completely we hold such defendants liable, including claims that would not meet the full individualisation test, or claims that are too small to be litigated individually, the better the deterrence effect is served. This leads to the question of what is expected of remedies.

Ideas ranging from a purely compensatory logic to deterrence-based approaches are used to explain the goals of remedies. The former seeks to right past wrongs to the extent possible, addressing claims by those who suffered violations and their consequences. The goal of deterrence, on the other hand, is more concerned with preventing violations that have not yet occurred. The latter is prospective or future-oriented, while the former is retrospective or past-oriented. Retrospective remedies seek damages and compensation for past harms without necessarily being preoccupied with what will happen in similar future cases.

If we consider the deterrence effect that any type of remedy ought to exert on potential tortfeasors, these distinctions quickly dissolve. Compensation paid by wrongdoers will have an inherent effect on future behaviour. While in some cases - eg in the determination of the precise amount of damages - the choice of approach will be significant, the two goals often go hand in hand. Compensation and guarantees of non-repetition are usually seen as two distinct types of reparation; ${ }^{131}$ however, on a more general level, the two are inherently linked. Courts can seek to end violating practices by specifically ordering the cessation of certain activities (injunctions), as well as by making certain activities too costly to be worth pursuing. The law and economics literature describes this as the goal of optimal deterrence. ${ }^{132}$ It is clear that collective procedures could help this goal considerably and lead to better enforcement, if they are designed well. Van den Bergh and Visscher discuss the ways in which collective procedures could address the problem of underenforcement in the European consumer protection context. ${ }^{133}$

Michael Thad Allen offers an interesting account of how the logic of deterrence can inform compensation calculations. He considers the difference between quantum meruit (the value of service/labour) and unjust enrichment (profit) as a way of calculating forced labour compensation in Nazi Germany. He argues that such a calculation might create new injustices: restitution claims tend to distort history. Establishing compensatory amounts based on gains might differentiate between companies based on their economic performance

131 UNGA Res 60/147, 'Basic Principles and Guidelines on the Right to a Remedy and Reparation for Victims of Gross Violations of International Human Rights Law and Serious Violations of International Humanitarian Law' (n 57) arts 11 and 19-23.

${ }_{132}$ S Shavell, Foundations of Economic Analysis of Law (Belknap Press 2004) 280-7.

133 R Bergh and L Visscher, 'The Preventive Function of Collective Actions for Damages in Consumer Law’ (2008) 1 Erasmus Law Review 5. 
rather than on the harm they have inflicted, potentially shielding an employer whose performance is low or negative. ${ }^{134}$

It could be argued that in the human rights context, enforcing damages could or should not be the most important element, even when it constitutes the core of the legal claim, because "class action litigation may bring public attention to human rights atrocities'. ${ }^{135}$ Litigation and the seeking of compensation can be part of a broader strategy, ${ }^{136}$ which is best understood if we take a 'public law' view of what courts (ought to) do, or what law and litigation are good for. ${ }^{137}$ Only complex remedies can adequately address complex violations, which is often the case with lasting, systemic minority rights violations. Collective procedures can help in this conundrum by providing more possibilities for courts to design a set of remedies covering a broad class of plaintiffs.

From a policy perspective, the changes that collective procedures are able to trigger might not be best captured by the legal nature of the remedy actually sought. While an injunction or a declaratory judgment is usually seen as leaning toward a push for change, damages may ultimately be more effective in influencing decision-makers through deterrence because they make potential defendants internalise the economic costs of the harm. The price tag that damages represent might also make defendants (as well as the public) aware of the actual harm they are causing.

It is easier for defendants to oppose and defeat a court-mandated desegregation plan than it is to question the loss of the life opportunities of children forced into segregated environments and to refuse to pay them compensation. This is not to say that failure to compensate is impossible, but it is probably more likely in a legal system that diverts from rule of law commitments. The Hungarian experience with school desegregation litigation illustrates the potential of aggregation even in hostile political environments.

Desegregation of schools for Hungarian Roma started in the 2000s. The underlying legal framework was adopted in 2003 as a run-up to EU accession, going, in fact, beyond the requirements of the Racial Equality Directive. ${ }^{138}$ Subsequently, a series of judgments established the widespread practice of school segregation and ordered desegregation. ${ }^{139}$ Procedurally, this took place through representative actions started by an NGO, without the

\footnotetext{
134 MT Allen, 'The Limits of Lex Americana: The Holocaust Restitution Litigation As a Cul-DeSac of International Human-Rights Law' (2011) 17 WidenerLRev 1.

135 KR Johnson, 'International Human Rights Class Actions: New Frontiers for Group Litigation' [2004] Michigan State Law Review 643, $655 . \quad 136$ ibid 656.

137 D Rosenberg, "The Causal Connection in Mass Exposure Cases: A "Public Law" Vision of the Tort System' (1984) 97 HarvLRev 849.

138 Racial Equality Directive (n 105). The Hungarian law (Act No 125 of 2003) established, among others, the possibility of representative action, which was not part of the acquis.

139 A Zimová, Strategic Litigation Impacts: Equal Access to Quality Education (Open Society Foundations 2016) 43-5.
} 
need to recruit plaintiffs. ${ }^{140}$ The trend was broken with the 2010 regime change in Hungary, which introduced a policy that seeks to legalise and even promote segregation under the pretext of religious education. This policy undermines the desegregation standards established in 2003, and risks undoing the progress made by successful desegregation litigation.

If all achievements are lost, the only remaining avenue might be to revert to tort law. Indeed, this possibility has already been explored in one high-profile case where, instead of directly asking for an end to segregation, the litigants sought compensation, in an aggregated fashion, for the harm caused by segregation. ${ }^{141}$ The effectiveness of this strategy is evidenced by the fact that the governing majority responded by amending the Act on Public Education to rule out financial compensation as a remedy ${ }^{142}$ in a blatant violation of rule of law requirements. The case demonstrates how compensation might be the last resort for challenging practices that victimise minorities, with the caveat that an overhaul of rule of law guarantees may reach a point where no legal action can override the political tide of anti-minority measures (save for intervention by European institutions). Short of such a political override, mass compensation seems to be a powerful tool. In the Hungarian case, 63 students asked for compensation, but one can imagine the transformative potential of thousands of former and current students harmed by segregated and substandard education coming forward with claims.

In Cordella and Others $v$ Italy, the ECtHR merged applications filed by 180 applicants that arose from the same polluting activity into a single procedure. ${ }^{143}$ While the applicants wanted a pilot judgment, the Court considered it unnecessary. It referred to the complexities of the case and simply noted that, regardless, Italy has an obligation to act vis-à-vis all those concerned, and not only the applicants. ${ }^{144}$ The Court then moved to dismiss the applicants' request for non-pecuniary damages with the usual formula that the finding of violation should suffice as a remedy. ${ }^{145}$

Without discussing the specifics of the case, it is easy to see how the deterrence effect of the judgment could have been improved by a long line of damages threatening Italy in the event of continued non-compliance. The ability to rule on damages beyond the named applicants to the entire class of

140 For a detailed first-person overview, see L Farkas, 'Mobilising for Racial Equality in Europe: Roma Rights and Transnational Justice’ (PhD Thesis, European University Institute 2020) <https:// cadmus.eui.eu//handle/1814/66916>.

${ }^{141}$ L Farkas, 'The EU, Segregation and Rule of Law Resilience in Hungary' (Verfassungsblog, 8 March 2020) <https://verfassungsblog.de/the-eu-segregation-and-rule-of-law-resilience-inhungary/ $>$.

142 A Kádár, 'Hungary, Flash Report, Draft Bill on Mandatory In-Kind Compensation for Segregation in Education Submitted' (European network of legal experts in gender equality and non-discrimination 2020) <https:/www.equalitylaw.eu/downloads/5197-hungary-draft-bill-onmandatory-in-kind-compensation-for-segregation-in-education-submitted-97-kb $>$.

143 Cordella and Others $v$ Italy App Nos 54414/13 and 54264/15 (ECtHR, 24 January 2019) para 92 and Annex. $\quad 144$ ibid paras 179-180. 145 ibid para 187. 
victims would have allowed the Court to add real bite to the finding of a violation. In addition, this would have served the goal of compensating those who had not joined the application (which could be for a variety of reasons, including lack of information). Furthermore, obliging the party responsible for the violation to identify all potential victims can be seen as part of taking responsibility for the action: in many cases, violators (and responding States) are better positioned to make such determinations, and this move can compensate for the informational disparity.

There are cases, however, where compensation is not the preferred remedy. Victims might be hostile to compensation, particularly in instances of egregious violations such as loss of life and sexual violence in wartime, but also with other human rights violations. In the case of disappearances, family members might be reluctant to accept compensation because this could be seen as an acknowledgment that their loved one will not come back. Payments in the Indian Residential Schools Settlement in Canada also had a less-than-ideal impact on victims. ${ }^{146}$ Similarly, compensation might be seen as offending if seen as 'paying off' rape. The judgment granting damages might seem like a 'forced sale', resulting in a devaluation of life, health, bodily integrity, or emotional suffering:

when it is the wrongdoer who chooses whether, when, and - to a large extent - at what price injury will be inflicted ... Money damages can never fully compensate for personal injuries that result in death or severe disability. Translating such losses into dollars and cents ... demeans the individual rights at stake. ${ }^{147}$

In these cases, collective procedures may allow courts to order a type of collective remedy, such as commemoration, research aimed at a better historical understanding, or free services for the victims and their families (all remedies that lack strict individualisation), when these might better serve the goal of remedies, even when remedies are construed in a strictly individualist reading. On the other hand, it is the definitive closure of a matter by compensation that makes collective procedures attractive to defendants: they can be freed from future claims by agreeing to a one-time award.

In conclusion, aggregation, which may at first glance seem to be a mere question of numbers, will result in a qualitative change that might determine outcomes and contribute to deterrence. Allowing claims to be litigated in an aggregated fashion can broaden the scope of the application of substantive rights. Courts will be more likely to discover and address patterns of rights violations as opposed to isolated cases or acts. ${ }^{148}$ The class action literature recognises the transformative potential of procedural rules allowing

146 T Carr, B Chartier and T Dadgostari, "I'm Not Really Healed ... I'm Just Bandaged up": Perceptions of Healing among Former Students of Indian Residential Schools' (2017) 12 IJIH 39.

147 Rosenberg (n 137) 878-9.

148 Rosenberg (n 137); LD Sargentich, 'Complex Enforcement' (1978) (unpublished manuscript). 
aggregation, ${ }^{149}$ which often changes the content of the underlying substantive rights.

\section{H. Collective Procedures and Improving the Judicial Process by Enhancing Coherence and Efficiency}

Listing the advantages and disadvantages of class action in general, ${ }^{150}$ Judge Jack B Weinstein discussed the reduction of duplication, in discovery and other procedural aspects, including appeal. This allows a judge to have a more holistic view of the case, ${ }^{151}$ helps in consistency and facilitates closure (through a single judgment or facilitating global settlements). Consistencyequal results - will satisfy a basic sense of justice about similar cases being decided alike. On the other hand, defendants might benefit from the fact that their liability is more calculable, or at least appears as 'a single fair punitive damage amount instead of repetitive and overlapping punishment'. ${ }^{152}$ The wider public also benefits from aggregation, as 'class actions serve broader public interests by effectively remedying and deterring civil rights violations and especially systemic discrimination'. ${ }^{153}$

Consistency is served when the result of and liability for widespread damages are judged in one lawsuit, rather than through a series of cases. This is especially so with public law litigation. Brandon L Garrett argued that in the case of developing constitutional values, '[b]igger lawsuits may sometimes be better' than a purely individual approach: 'If constitutional litigation becomes a purely solitary affair, sporadic cases may have an outsized impact, but in an ad hoc way that provides poor notice to government officials. Aggregation can improve clarity, legitimacy, participation, and representation.' 154

Consistency does not only mean that the same standards are applied to all defendants found liable for a particular violation, or that the same types of remedies and amounts of damages are awarded, but also that there is a hierarchy of claims, and that some payments should be made before others. Such considerations are decisive in the case of limited funds. Budgetary constraints are a legitimate concern with respect to claims for widespread violations, especially in the context of transitional justice. Under traditional judicial treatment, early claims might end up consuming the funds available, assuming that there are available funds in the first place - a central concern in the practice of mass violations claims. Claims aggregation, a measure used in

149 Greenberg, 'Civil Rights Class Actions: Procedural Means of Obtaining Substance' (n 73); T Eisenberg and SC Yeazell, 'The Ordinary and the Extraordinary in Institutional Litigation' (1980) 93 HarvLRev 465; RH Klonoff, EKM Bilich and S Malveaux, Class Actions and Other Multi-Party Litigation: Cases and Materials (2nd edn, Thomson/West 2006) 7.

150 JB Weinstein, 'Compensating Large Numbers of People for Inflicted Harms' (2001) 11 DukeJComp\&Intl L 165, 172-4. $\quad{ }^{151}$ Garrett (n 99) 613. $\quad{ }^{152}$ Weinstein (n 150) 173.

153 'Brief for the NAACP Legal Defense \& Educational Fund, Inc. as Amici Curiae Supporting Respondents, AT\&T Mobility LLC v Concepcion, 131 S. Ct. 1740’ (n 71) 3.

154 Garrett (n 99) 648. 
class actions, aims at solving this problem, by denying exclusive preference to claims made prior to other claims.

Aggregation and economies of scale allow for more focused and better funded work on discovery and legal strategies. Aggregation can improve legitimacy through greater participation, access to information, better representation and discovery, as well as allowing for a more effective use of resources. ${ }^{155}$ Aggregation can level the playing field for plaintiffs with fewer resources who might lose out if forced to pursue individual litigation. Instead of favouring 'the most assertive ones, those with the highest education and sometimes the most wealthy' ${ }^{\prime} 156$ collective procedures can benefit the entire victim group. 'Aggregation may result in greater equality in results. ${ }^{157}$ If we are concerned with vulnerable group members, this is a key benefit.

\section{CONCLUSION: LIMITS, CHALLENGES AND BENEFITS}

Collective procedures present promising opportunities for the better implementation and enforcement of minority rights. They can contribute to empowerment by giving voice and weight to victims and by allowing claims that do not fit the strictly individualist framework to be legally cognisable. They can provide balance to majority biases that misrecognise claims and their contexts. They present a set of cases and victims and reduce the likelihood of claims being thrown out simply because courts are unwilling to engage with the broader context that makes violations apparent, including, among other things, statistical evidence. The resulting broader view allows courts to shift the burden of proof for individual claims, even where the legislature has not provided for that rule. Collective procedures can boost minority claims by relying on aggregation and economies of scale in representation, discovery and organisation alike. In addition, by distributing any remedies awarded across the entire group, including its less affluent members, collective procedures remediate equality claims in a manner that also acts against internal inequalities within the group.

The procedural approach achieves these goals without upsetting the overall individualist framework of the legal system. Admittedly, collective procedures are sometimes seen as antithetical to party autonomy because they do not allow those concerned to have their days in court. A proper reading, however, reveals how this criticism applies to both individual and collective actions: individual litigation can bring about changes touching upon individual interests not represented in the litigation. In contrast, collective procedures have built-in guarantees for assessing the fairness of representation, with room for acknowledging and accommodating variation within the claimant group.

Another concern posits collective responses outside the scope of proper judicial action and voices a fear of the politicisation of courts. Again, we

\footnotetext{
155 Garrett (n 99) 613.

156 Walleyn (n 76) 363.

157 Garrett (n 99) 613.
} 
should begin by acknowledging that rights enforcement happens in a political context. Public law remedies often require policy reforms and action by political bodies. Similarly, human rights litigation tends to seek broader political changes, regardless of whether the underlying procedure is individual or collective. Collective procedures make this aspect more apparent, forcing courts to deal with it more consciously.

A related criticism is that courts cannot cope with complex patterns of violations. However, experiences with collective actions show that they can help courts design remedies that effectively address complex and widespread violations. This includes combining collective and individualised remedies, which also addresses the criticism that collective procedures disregard individual variation and concern for individual justice. We have seen that complex damages resulting from losses of life and culture, or oppression resulting in torture and illegal detention can indeed be addressed in a judicial setting. As part of a collective procedure, tools such as statistical sampling can serve consistency and judicial efficiency, as well as mitigating the problem of limited funds.

One could reject collective procedures as a US peculiarity and a tool to be confined to specific areas of law, such as competition law. It has been seen, however, a growing acknowledgment in other jurisdictions, including the ECtHR, that effective implementation of human rights should include comprehensive responses to mass phenomena. The alternative is not only judicial logjam but a denial of justice. Individualist selectivity is problematic not only when the filtering described reflects an inherent difference. If such an individualistic approach arbitrarily neglects values and interests, that will, in turn, call into question the basic functioning and legitimacy of the legal system.

Collective remedies can extend the law's ability to recognise legitimate claims in two interrelated ways. First, it allows us to see that collective forms of remedies can be applied in more areas than is usually assumed. Second, where they do (or should) apply, they can provide benefits that are not available under a strictly individual scheme.

What the argument does not claim is that a collective remedy will always be superior. Many minority claims will still be litigated via individual lawsuits, actio popularis and representative action. Collective procedures should be seen as complementary, expanding the scope of the judicial enforcement of minority rights.

The call, in this article, to allow minority rights litigation to reap the benefits of collective procedures comes with another caveat. As much as judicial sanctions require some level of political commitment to rights and the rule of law-short of which legal guarantees will make little difference-judicial (and quasi-judicial) avenues cannot cover all aspects of minority rights. Struggles for self-government can well be phrased as a matter of rights, but this goal is seldom reached through judicial enforcement. 
All this means that lawmakers would be well advised to adopt a framework that allows for collective procedures in minority rights enforcement, particularly when it is politically difficult to strengthen minority rights through substantive - non-procedural-measures. ${ }^{158}$ This article could not explore the concrete forms and technical details of what specific rules this requires, since that would depend on the specificities of the given jurisdiction. What the overview did show is that such a move is an appealing option for bridging the gap between minority claims that include collective rights and legal systems that reject the legal recognition of minorities as groups.

There have been calls to refocus the global struggle for human rights on core legally binding obligations and to rein in perceived attempts to answer every social problem with an appeal to human rights law. ${ }^{159}$ More specifically for minority rights, it might make sense to work towards equality in areas that do not require major shifts such as the recognition of new collective or group rights.

What collective procedures offer is the opportunity to reap many of the benefits of the collective approach through the existing platform of individual rights. These procedures allow us to sidestep controversies around the expansion of rights and instead to focus on ensuring fundamental human rights guarantees for minorities by extending effective remedies to a more complete group of victims, while also contributing to optimal deterrence and a decrease in violating practices as a result.

The most important innovation that this approach could bring is its transformative potential: just as class actions for faulty products and services call attention to the full scope of damages, minority rights advanced in collective procedures can transform our vision of what violations do, what responses are due and, ultimately, what these minority rights are. What starts as a technical and procedural solution goes a long way in transcending the individual/collective minority rights divide, bringing us closer to the type of equality that is the promise of democracies and rule of law regimes.

\footnotetext{
158 See how the European Union that, in 2020, refused to act on the first European Citizens' Initiative and to take steps to improve the situation of national minorities in Europe ('Minority SafePack'), adopted a collective mechanism to address power imbalances in other areas (competition and consumer law, see earlier). While we can hardly expect EU action directly targeting and benefiting minorities, this does not exclude more general measures that help minorities, as has happened with non-discrimination measures that many minorities can rely on, including in areas like desegregation and harassment, as defined in the Racial Equality Directive (n 105).

159 For a recent argument to this end, see Hurst Hannum, Rescuing Human Rights: A Radically Moderate Approach (Cambridge University Press 2019).
} 